\title{
Saskatchewan's First Resident Bird-Watcher, Geo. F. Guernsey
}

By Stuart Houston, M.D., Yorkton, Sask.

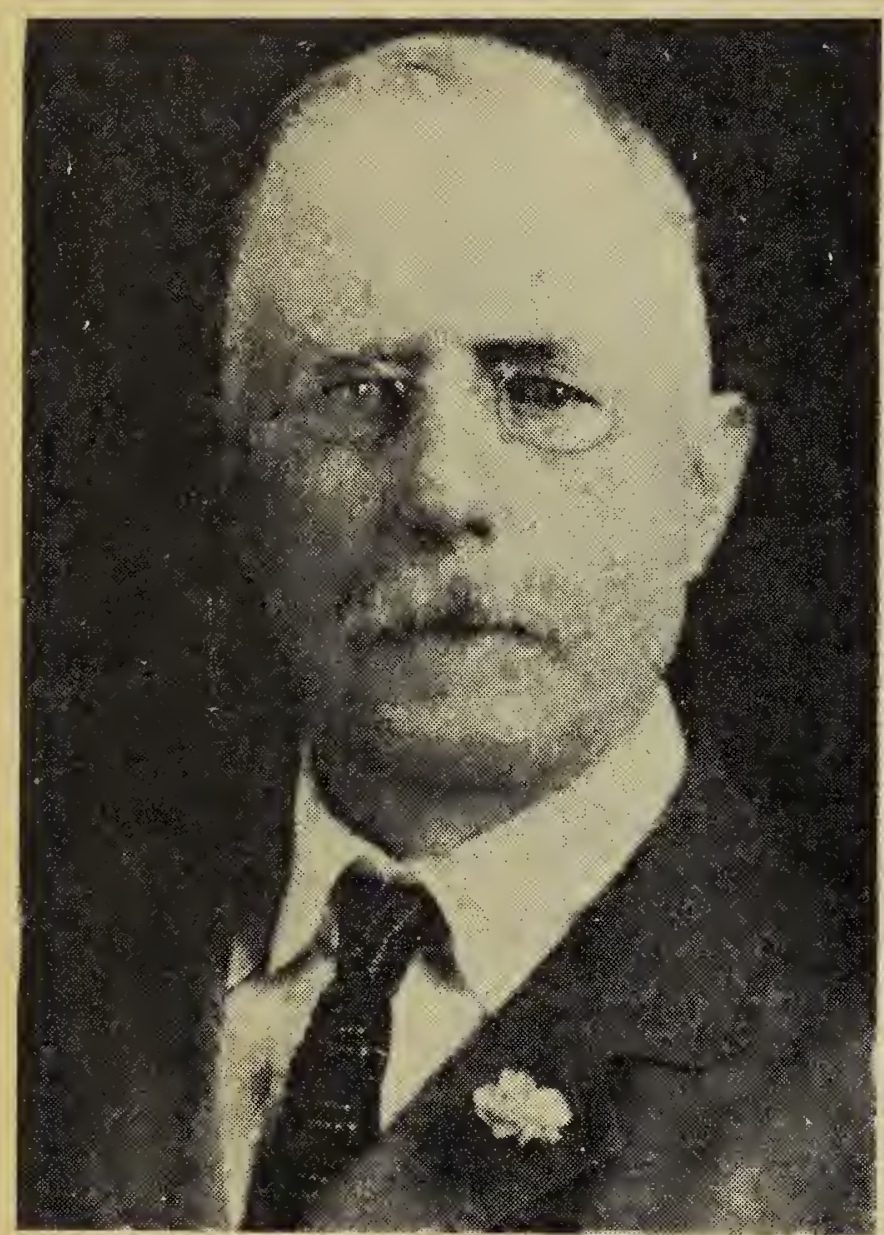

Sir John Richardson, Thomas Drummond, and Captain Thomas Blakiston all made important studies cf Saskatchewan birds, the first two in the 1820's and the latter in the 1850's. However, they were members of exploring expeditions and only temporary visitors. The first resident bird-watcher of whom we have record was George F. Guernsey.

Guernsey's bird records were used in the Birds of Western Manitoba by Ernest E. T. Seton, publishd in The Auk in April and June of 1886. Seton in his introduction said, "The observations for the region are my own, as I have visited nearly every part of it. I have, however, received much valuable assistance from $\mathrm{Mr}$. G. F. Guernsey, who is responsible for the records from Qu'Appelle." In 1891, the Smithsonian Institute published a revised and enlarged work entitled The Birds of Manitoba, by Ernest E. Thompson (Seton's alternate name). This gave Guernsey's observations more fully with 96 species listed from Fort Qu'Appelle, with spring migration dates given for most of these. When one considers that books on birds for the amateu were virtually non-existent, and tha identification was made at that tim largely from collected specimens, thi number of sight records is ver: creditable indeed. Ninety-three 0 the 96 are acceptable to this writer only three being open to seriou question (Greater Scaup, Field Spar row, Swamp Sparrow). Some of th Fort Qu'Appelle migration dates wer for 1885; it is not clear whether th majority were from 1884, and only few addenda from 1885, or whethe all were from 1885.

Here is Guernsey's list of 96 spec ies observed at Fort Qu'Appelle, wit. indications of their status in th area, and first arrival dates:

Common Loon: Common summe resident; breeds; arrival April 2 White Pelican: Common summer resi dent; very plentiful on lakes in 188 Toward migratory season I saw flock of upwards to 500 birds (letter $\mathrm{Ma}$ 18,1885 ).

Diouble-crestiad Cormorant: Rathe common summer resident; breeds arrival about April 25.

Great Blue Heron: Tolerably commo summer resident; breeds; arrive May 6.

American Bittern: Common summe resident; breeds; arrives May 21.

Canada Goose: Common summer res dent; breeds; April 1 to 10.

Snow Goose: Transient; passing ove May 3 to 28.

Mallard: Common summer residen breeds; April 5 to 15 .

Gadwall: Common summer residen breeds; April 20.

American Widgeon: Common summe resident; breeds; April 20.

Pintail: Common summer residen breeds; April 5 to 15

Shoveler: Common summer residen breeds; May 1.

Wood Duck: I know of one bein shot here in 5 years.

Green-winged Teal: Common summe resident; breeds; April 5 to 15.

Blue-winged Teal: Common summe resident; breeds; May 10.

Redhead: Common summer residen breeds; April 23. 
Ring-necked Duck: Common summer resident; breeds; arrives April 20.

Canvasback: $\mathrm{C}$ o $\mathrm{m} \mathrm{m}$ o $\mathrm{n}$ migrant; April 23.

Greater Scaup: Common summer resident; breeds; arrives April- 20 in flocks with Lesser Scaup and Ringnecked.

Lesser Scaup: Common summer resident; breeds; arrives April 20.

Common Goldeneye: Tolerably common summer resident; breeds; arrives April 15.

Bufflehead: Common summer resident; breeds; arrives Sept. 20.

Ruddy Duck: Common summer resident; breeds; May 1.

White-winged Scoter: Common $\mathrm{mi}$ grant; May 1.

Surf Scoter: Rare migrant; May 1; Specimen taken in fall of 1883 .

Hooded Merganser: Common summer resident; breeds; arrives April 20.

Common Merganser: Tolerably common summer resident; May 5.

Red-breasted Merganser: Tolerably common summer resident; May 1.

Turkey Vulture: Common summer resident; breeds; arrives May 20.

Bald Eagle: Occasional; does not breed; April 30.

Marsh Hawk: Comon summer resident; breeds; arrives April 15.

Osprey: Occasional summer resident.

Pigeon Hawk: Tolerably common; arrives April 20.

Sparrow Hawk: Commcn summer resident; breeds; arrives April 15.

Ruffed Grouse: Common; permanent resident; breeds.

Sharp-tailed Grouse: Common; permanent resident; breeds.

Whooping Crane: Transient; passing over April 28 to May 1.

Sandhill Crane: Transient; passing over April 28 to May 1.

American Coot: Common summer resident; breeds; arrives May 6 .

Killdeer: Common summer resident: breeds; arrives April 17.

American Golden Plover: Tolerably common migrant; May 20.

Upland Plover: Common summer resident; breeds; arrives May 12.

Common Snipe: Common summer reident; breeds; arrives April 20.

Greater Yellowlegs: C o m m o n migrant; May 5.

Lesser Yellowlegs: Common migrant; May 5 .

Marbled Godwit: Common summer resident; breeds; arrives May 10.

American Avocet: Occasional; plentiful on alkali ponds to the west.
Black Tern: Common summer resident; breeds; arrives May 18.

Mourning Dave: Common summer resident; breeds; arrives May 12.

Passenger Pigeon: Occasional; May 10.

Black-billed Cuckoo: (noted)

Great Horned Owl: Occasional; not common.

Snowy Owl: Have seen specimens but not common.

Whip-p.oor-will: Occasional.

Common Nighthawk: Common summer resident; breeds; arrives May 21. Ruby-threatid Hummingbird: Occasicnal; not plentiful.

Belted Kingfisher: Tolerably common summer resident; breeds.

Yellow-shafted Flicker: Common; summer resident; arrives April 25.

Hairy Woodpecker: Tolerably common; permanent resident.

Eastern Kingbird: Common summer resident; breeds; arrives May 24.

Eastern Phoebe: Tolerably common summer resident; arrives May 20.

Horned Lark: Common summer resident; arrives April 1 to 25.

Tree Swallow: Summer resident; breeds; arrives about May 10.

Bank Swallow: Summer resident; breeds; arrives about May 10 .

Barn Swallow: Summer resident; breeds; arrives about May 20.

Cliff Swallow: Summer resident; breeds; arrives about May 10.

Blue Jay: Tolerably common summer resident; arrives May 6.

Black-billed Magpie: Occasional; plentiful 100 miles north.

Common Raven: Occasional.

Common Crow: Common; breeds; April 1 to 5 .

Black-capped Chickadee: Common permanent resident; breeds.

House Wren: Common summer resident; breeds; arrives May 12.

Short-billed Marsh Wren: Common summer resident; breeds; arrives May 15.

Catbird: Common summer resident; breeds; arrives about May 15.

Robin: Common summer resident; flocks of 4 to 5 about April 12 .

Veery: Tolerably common summer resident; arrives about May 20.

Cedar Waxwing: Common; arrives May 22.

Loggerhead Shrike: Common; breeds. Yellow Warbler: Common summer resident.

Bobolink: Tolerably common summer resident; breeds; arrives May 15. 
Western Meadowlark: Common summer resident; breeds; arrives April 5. Yellow-headed Blackbird: Common summer resident; breeds; arrives April 18.

Redwinged Blackbird: $\mathrm{C}$ o $\mathrm{m} m$ o $\mathrm{n}$ summer resident; breeds; arrives April 18.

Baltimore Oriole: Common summer resident; breeds; arrives May 18.

Common Grackle: Common summer resident; breeds; arrives April 25.

Brown-headed Cowbird: $\mathrm{C}$ o $\mathrm{m} \mathrm{m}$ o $\mathrm{n}$ summer resident; breeds; arrives April 20.

Scarlet Tanager: Occurs sometimes but is rather rare.

Evening Grosbeak: Common winter visitor; large flocks seen in Feb. and March.

Pine Grosbeak: Common winter visitor; large flocks seen all winter.

Common Redpoll: Common; arrives April 1.

American Goldfinch: Tolerably common; summer resident; breeds; arrives May 24.

Chipping Sparrow: Summer resident; breeds; arrives April 13.

Field Sparrow: Common summer resident; breeds; arrives April 15.

Swamp Sparrow: Common summer resident; breeds; arrives September 18.

Song Sparrow: Common summer resident; breeds; arrives April 1 to 5 .

Snow Bunting: Common winter visitor; leaves about May 10.

George Forbes Guernsey was born Nov. 6, 1861, in Aldershot, England, the eldest son of Major Forbes William Guernsey of the 45th First Nottinghamshire Regiment - Sherwood Foresters. He spent some time in India as a boy, and lived in Dublin and London until his father retired from the Army and brought his family to Port Hope, Ont. in 1871. Young George was articled to a lawyer in Port Hope, but before finishing his law course he came west and joined the Royal North West Mounted Police at Fort Walsh on Aug. 21, 1880. He was a member of " $B$ " Division and served chiefly at Fort Qu'Appelle. He was part of the escort for the Marquis of Lorne when he visited the "Wild West." He received the North West Rebellion medal, and had three sketches illustrating Riel Rebellion activity published in the Illustrated War News of Toronto on May 9, 1885. He took his discharge from the R.N.W.M.P. on Dec. 12,
1886, but was immediately re-engaged as a Special Constable until June 21,1887 . We are told that it was because of the good duck-hunting and fishing that he remained to settle at Fort Qu'Appelle (then in Assiniboia, N.W.T.). He was a magistrate, rotary public and insurance agent. E. M. Miller, Q.C. of Regina reports that when he worked for Guernsey in the early 1900's, Guernsey was an auctioneer and general agent, and was the Dominion election agent, keeping a voters' list and registering all vital statistics. His home was about a mile frcm town, along what is now the road to the San. He married Charlotte Morrison and they had four children: George Forbes Jr., Eva, Laura (who died in infancy) and Elizabeth. I am indebted to Miss Eva Guernsey, of Vancouver, for most of the information given in this article.

Mrs. Guernsey died in 1903, an Mr. Guernsey later married Winnifred Morgan. They had two sons Charles and Terrence, born in Penticton where the family moved about 1907. In Penticton, Guernsey was a prominent citizen, serving as magistrate, president of the Conservative Association and recruiting officer ir the first world war.

George Guernsey was always in terested in wild life of every kind At Fort Qu'Appelle his children hac a succession of pet crows and ever a Sandhill Crane which would follow Mrs. Guernsey around like a dog His son had a collection of birds' eggs At Penticton, he kept Mallards or the pond near his home, and these attracted many other ducks. He ofter went on the "speeder" with work crews on the Kettle Valley Railroad to fish in mountain lakes. He was in. strumental in releasing pheasants ir the Penticton area. He also had : small orchard of choice fruit trees and was fond of gardening.

For years, Guernsey wrote article for Rod and Gun and for the Mountec Police annuàl Scarlet and Gold under the name of "Waseecha Hos. ka." This was Indian for "long whit man," the name the Indians hac given him on the prairies (he stoor six feet tall in his sock feet).

He retired in 1935 and died Apri 6,1937 , in Penticton at the age of 75 At his funeral, he was accorded ful military honors, including a firin party. 